Article

\title{
Extraction and Isolation of Kaempferol Glycosides from the Leaves and Twigs of Lindera neesiana
}

\author{
Anjana Adhikari-Devkota ${ }^{1}$, Amina Ibrahim Dirar ${ }^{1}$, Ayumi Kurizaki ${ }^{2}$, Kazuki Tsushiro ${ }^{2}$ and \\ Hari Prasad Devkota $1,3, *$ (D) \\ 1 Graduate School of Pharmaceutical Sciences, Kumamoto University, 5-1 Oe-honmachi, Chuo-ku, \\ Kumamoto 862-0973, Japan; adhikarianjana@gmail.com (A.A.-D.); aminadirar2007@gmail.com (A.I.D.) \\ 2 School of Pharmacy, Kumamoto University, 5-1 Oe-honmachi, Chuo-ku, Kumamoto 862-0973, Japan; \\ 130p1019@st.kumamoto-u.ac.jp (A.K.); 131p1035@st.kumamoto-u.ac.jp (K.T.) \\ 3 Program for Leading Graduate Schools, Health Life Science: Interdisciplinary and Glocal \\ Oriented (HIGO) Program, Kumamoto University, 5-1 Oe-honmachi, Chuo-ku, Kumamoto 862-0973, Japan \\ * Correspondence: devkotah@kumamoto-u.ac.jp; Tel.: +81-96-371-4381
}

Received: 11 January 2019; Accepted: 5 February 2019; Published: 13 February 2019

\begin{abstract}
The hydroalcoholic extract of leaves and twigs of Lindera neesiana (Wall. ex Nees) Kurz (Lauraceae) was subjected to various column chromatographic methods that isolated five kaempferol glycosides: kaempferol 3-O- $\beta$-glucopyranosyl $(1 \rightarrow 2)$-[ $\alpha$-rhamnopyranosyl-( $1 \rightarrow 6)]-\beta$-glucopyranoside7-O- $\alpha$-rhamnopyranoside (1); kaempferol 3-O- $\beta$-glucopyranosyl-( $(\rightarrow 2)$-[ $\alpha$-rhamnopyranosyl $(1 \rightarrow 6)]-$ $\beta$-glucopyranoside (2); kaempferol 3 -O- $\beta$-glucopyranosyl $(1 \rightarrow 2)-\alpha$-rhamnopyranoside-7-O- $\alpha$ rhamnopyranoside (3); kaempferol 3-O-sophoroside (4); and kaempferol 3-O- $\alpha$-rhamnopyranoside (5). The extract showed moderate free radical scavenging activity and potent pancreatic lipase inhibitory activity.
\end{abstract}

Keywords: Lindera neesiana; Siltimur; kaempferol glycosides; free radical scavenging; lipase inhibitory

\section{Introduction}

The genus Lindera (Family: Lauraceae) consists of about 100 species widely distributed in tropical, subtropical, and temperate zones of Asia and Midwestern America [1]. Various species of Lindera plants are used in traditional medicine for the treatment of different ailments including rheumatoid arthritis, stroke, cholera, diarrhea, toothache, and nausea [1-3]. Lindera plants are a rich source of fatty and essential oils that are used for the production of soaps, lubricants, spices, fragrances, and timber [1]. Different types of secondary metabolites have reportedly been isolated from Lindera plants including sesquiterpenoids, alkaloids, butanolides, lucidones, phenylpropanoids, isocoumarins, and lignans [1,4-6]. Flavonoids have also reportedly been isolated from several Lindera plants including Lindera umbellata, Lindera lucida, Lindera erythrocarpa, Lindera aggregata, and Lindera obtusiloba $[7,8]$. Lindera plants and isolated compounds have been studied for different biological activities including cytotoxic [9,10], anti-inflammatory [11,12], anti-hypertensive [13], hepatoprotective [14], and antioxidant activities [15,16].

Lindera neesiana (Wall. ex Nees) Kurz commonly known as 'Siltimur' in Nepal, is a small tree distributed in Nepal, India, Bhutan, and Myanmar [2,17]. The fruits are aromatic and are used as a spice in preparation of various food products as well as traditional medicines to treat diarrhea, tooth pain, headache, and gastric disorders $[2,17,18]$. Essential oils from L. neesiana fruit consisted mainly of $Z$-citral, E-citral, eucalyptol, citronellal, $\alpha$ pinene and $\beta$ pinene, and showed potent antibacterial and antifungal effects [19]. The water extract from these fruits also showed potent neuroprotective and anti-neuroinflammatory activity [18]. However, there was no study on the chemical constituents of 
the leaves and twigs. In a previous study, we isolated several flavonoids from the leaves and twigs of Lindera sericea, which is widely used as a herbal tea in Japan, and evaluated its free radical scavenging and enzyme inhibitory activities [20]. Thus, in this study, we aimed for the isolation and identification of chemical constituents and the evaluation of free radical scavenging and pancreatic lipase inhibitory activities of the extract and compounds.

\section{Materials and Methods}

\subsection{General Experimental Procedures}

The ${ }^{1} \mathrm{H}-,{ }^{13} \mathrm{C}$ - and $2 \mathrm{D}-\mathrm{NMR}$ spectra were measured on a AVANCE-I 600 NMR spectrometer (Bruker, Billerica, MA, USA) $\left({ }^{1} \mathrm{H}-\mathrm{NMR}: 500 \mathrm{MHz}\right.$ and $\left.{ }^{13} \mathrm{C}-\mathrm{NMR}: 125 \mathrm{MHz}\right)$ using $\mathrm{CD}_{3} \mathrm{OD}$ as solvent. Chemical shifts are given in ppm with reference to tetramethyl silane (TMS). Mass spectra were recorded on a JEOL JMS 700 MStation mass spectrometer. Absorbance was recorded on an Infinite 200 $\mathrm{PRO}^{\circledR}$ (Tecan Austria GmBH, Grodig, Austria). Column chromatography (CC) was carried out with a MCI gel CHP20P (75-150 m, Mitsubishi Chemical Industries Co. Ltd., Tokyo, Japan), Sephadex LH-20 (Amersham Pharmacia Biotech, Tokyo, Japan), Chromatorex ODS (30-50 $\mu \mathrm{m}$, Fuji Silysia Chemical Co., Ltd., Aichi, Japan), and silica gel 60 (0.040-0.063 mm, Merck KGaA, Darmstadt, Germany). Thin layer chromatography (TLC) was performed on a pre-coated silica gel $60 \mathrm{~F}_{254}$ (Aluminum sheet, Merck KGaA, Darmstadt, Germany).

\subsection{Plant Materials and Chemicals}

The fresh leaves and twigs of Lindera neesiana were collected from Lumle, Kaski District, Nepal on February 2016 and shade dried for two weeks. Voucher specimens were deposited at the Museum of Traditional Medicines, School of Pharmacy, Kumamoto University, Kumamoto, Japan.

1,1-Diphenyl-2-picrylhydrazyl (DPPH), and porcine pancreatic lipase, were purchased from Sigma Aldrich Japan, Co. (Tokyo, Japan). Cetilistat was obtained from Combi-Blocks, Inc., San Diego, CA, USA. 6-Hydroxy-2,5,7,8-tetramethyl-3,4-dihydrochromene-2-carboxylic acid (Trolox) was obtained from Wako Pure Chemical Industries, Ltd. (Tokyo, Japan).

\subsection{Extraction and Isolation}

The dried leaves and twigs of Lindera neesiana $(2.3 \mathrm{~kg})$ were extracted twice with $60 \%$ ethanol (36 L) for two days by maceration at room temperature. The filtered extracts were combined and evaporated under reduced pressure to obtain $387.1 \mathrm{~g}$ of extract. The extract was then suspended in water and applied to MCI gel CHP20P CC (gel volume measured to about $600 \mathrm{~cm}^{3}$ ), then eluted successively with water, $40 \%, 60 \%, 80 \%$ and $100 \% \mathrm{MeOH}$ to give seven fractions (Fr. 1-Fr. 7 ) on the basis of their TLC patterns. Fraction 2 (27.0 g) was subjected to Sephadex LH-20 CC (water followed by MeOH) to obtain three subfractions (SubFr. 2-1 SubFr. 2-3). Subfractions 2-1 (20.7 g, water eluate) and 2-2 (3.6 g, water eluate) were combined as 2-1 (24.4 g) and subjected to ODS CC (water, 5\%, 10\%, 20\%, 30\%, 40\%, $50 \%$ and $100 \% \mathrm{MeOH}$ ) to obtain thirteen subfractions (SubFr. 2-1-1 SubFr. 2-1-13). Subfraction 2-1-5 ( $1.7 \mathrm{~g}, 5 \%$ eluate) was subjected to silica gel $\mathrm{CC}\left(\mathrm{CH}_{2} \mathrm{Cl}_{2}: \mathrm{MeOH}: \mathrm{H}_{2} \mathrm{O}=7: 3: 0.5\right)$ to obtain compound 1 (550 mg). Subfractions 2-1-6 (2.0 g, 5\% MeOH eluate) and 2-1-7 (1.3 g) were combined and subjected to silica gel CC $\left(\mathrm{CH}_{2} \mathrm{Cl}_{2}: \mathrm{MeOH}: \mathrm{H}_{2} \mathrm{O}=7: 3: 0.5\right)$ to obtain compound 1 (1630 mg). Subfraction 2-1-8 (1.5 g, $10 \% \mathrm{MeOH}$ eluate) was subjected to silica gel CC $\left(\mathrm{CH}_{2} \mathrm{Cl}_{2}: \mathrm{MeOH}: \mathrm{H}_{2} \mathrm{O}=7: 3: 0.5\right)$ to obtain compound 1 (600 mg). Subfraction 2-1-10 (1.0 g, 30\% eluate) was subjected to silica gel CC $\left(\mathrm{CH}_{2} \mathrm{Cl}_{2}: \mathrm{MeOH}_{2} \mathrm{H}_{2} \mathrm{O}\right.$ = 7:3:0.5) to obtain compound 2 (553 mg). Subfractions 2-1-11 (3.3 g, 40\% MeOH eluate) and 2-1-12 (1.3 g, 40\% MeOH eluate) were separately subjected to silica gel CC $\left(\mathrm{CH}_{2} \mathrm{Cl}_{2}: \mathrm{MeOH}: \mathrm{H} 2 \mathrm{O}=7: 3: 0.5\right)$ to obtain compound 2 (950 mg) and compound 3 (52 mg), respectively. Fraction 3 (13.1 g) was subjected to Sephadex LH-20 and eluted with 50\% MeOH to obtain four subfractions (SubFr 3-1 SubFr 3-4). Subfractions 3-2 (10.9 g) and 3-3 (1.2 g) were combined and applied to ODS CC (water, 10\%, 20\%, $30 \%, 40 \%, 60 \%$ and $100 \% \mathrm{MeOH})$ to obtain seventeen subfractions (3-2-1 3-2-17). Subfraction 3-2-7 
(2.8 g) was subjected to silica gel $\mathrm{CC}\left(\mathrm{CH}_{2} \mathrm{Cl}_{2}: \mathrm{MeOH}: \mathrm{H}_{2} \mathrm{O}=8: 2: 0.1\right)$ to obtain compound 2 (487 mg) and subfraction 3-2-8 $(0.8 \mathrm{~g})$ was subjected to silica gel $\mathrm{CC}\left(\mathrm{CH}_{2} \mathrm{Cl}_{2}: \mathrm{MeOH}: \mathrm{H}_{2} \mathrm{O}=8: 2: 0.1\right)$ to obtain compound $4(121 \mathrm{mg})$ and compound $2(180 \mathrm{mg})$. Subfraction 3-2-10 was subjected to silica gel CC $\left(\mathrm{CH}_{2} \mathrm{Cl}_{2}: \mathrm{MeOH}: \mathrm{H}_{2} \mathrm{O}=8: 2: 0.1\right)$ to obtain compound 3 (106 mg). Subfractions 3-2-11 (1.6 g), 3-2-12 $(0.8 \mathrm{~g})$, and 3-2-13 (1.8 g) were combined and subjected to silica gel CC $\left(\mathrm{CH}_{2} \mathrm{Cl}_{2}: \mathrm{MeOH}: \mathrm{H}_{2} \mathrm{O}=8: 2: 0.1\right)$ to obtain compound $3(200 \mathrm{mg})$ and compound $5(14 \mathrm{mg})$. Fraction $4(33.0 \mathrm{~g})$ was subjected to Sephadex $\mathrm{LH}-20(50 \% \mathrm{MeOH})$ followed by silica gel $\mathrm{CC}\left(\mathrm{CH}_{2} \mathrm{Cl}_{2}: \mathrm{MeOH}: \mathrm{H}_{2} \mathrm{O}=8: 2: 0.1\right)$ to obtain compound 5 (110 mg).

\subsection{Measurement of DPPH Free Radical Scavenging and Pancreartic Lipase Inhibitory Activities}

The DPPH free radical-scavenging and pancreatic lipase inhibitory activities were evaluated by using the previously described method [21].

\section{Results}

The leaves and twigs of Lindera neesiana $(2.3 \mathrm{~kg})$ collected at Lumle, Kaski District, Nepal were extracted with $60 \%$ ethanol to obtain $387.0 \mathrm{~g}$ of extract. The extract was then subjected to repeated column chromatography on MCI gel CHP20P, Sephadex LH-20, ODS, and silica gel to isolate five pure compounds (1-5) (Figure 1).

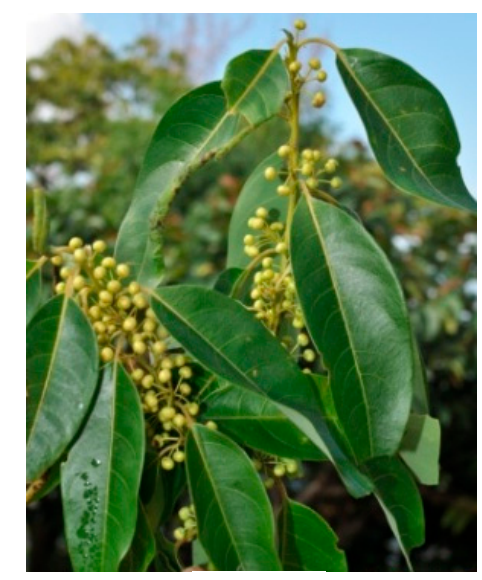

(a)

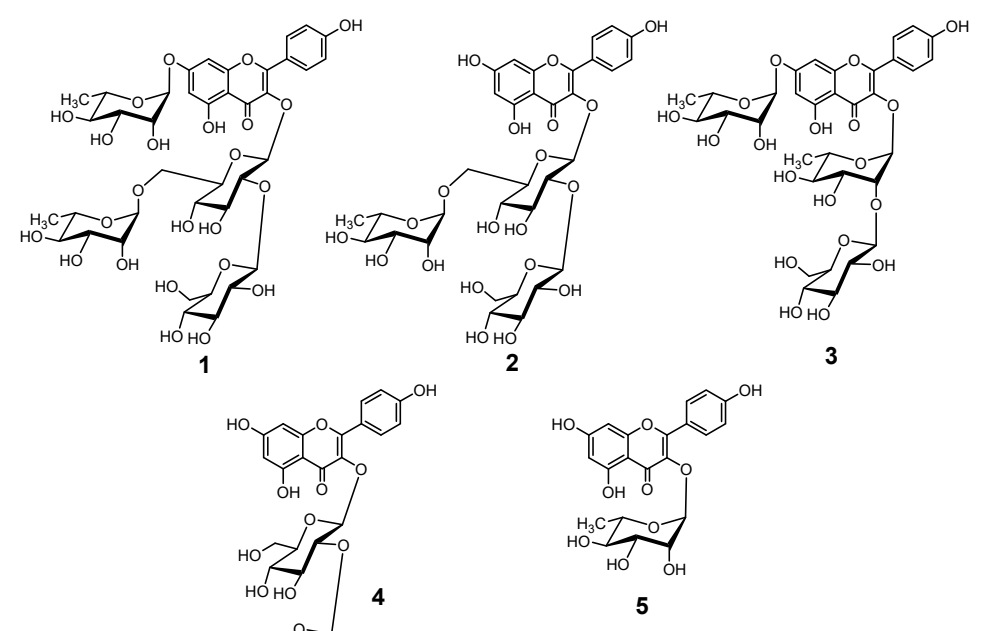

(b)

Figure 1. Photograph of Lindera neesiana (a) and the structures of compounds isolated from the leaves and twigs of Lindera neesiana (b).

Compound 1 was obtained as a yellow amorphous powder. The HR-FAB-MS of 1 showed the quasi-molecular ion $[\mathrm{M}+\mathrm{Na}]^{+}$peak at $m / z$ : 925.3637 (calculated for $\mathrm{C}_{39} \mathrm{H}_{50} \mathrm{O}_{24} \mathrm{Na}$ : 925.2590) supporting the formula $\mathrm{C}_{39} \mathrm{H}_{50} \mathrm{O}_{24}$. The ${ }^{1} \mathrm{H}-\mathrm{NMR}$ spectrum of $\mathbf{1}$ (Table 1) shows the signals for 3,7-disubstituted kaempferol moiety at $\delta_{\mathrm{H}} 8.05\left(2 \mathrm{H}, \mathrm{d}, J=8.8 \mathrm{~Hz}, \mathrm{H}-2^{\prime}, 6^{\prime}\right), 6.91(2 \mathrm{H}, \mathrm{d}, J=8.8 \mathrm{~Hz}$, $\left.\mathrm{H}-3^{\prime}, 5^{\prime}\right), 6.74(1 \mathrm{H}, \mathrm{d}, J=2.1 \mathrm{~Hz}, \mathrm{H}-8)$, and $6.46(1 \mathrm{H}, \mathrm{d}, J=2.1 \mathrm{~Hz}, \mathrm{H}-6)$. Furthermore, signals for four aromatic protons including two glucopyranosyl moieties at $\delta_{\mathrm{H}} 5.40(1 \mathrm{H}, \mathrm{d}, J=7.6 \mathrm{~Hz})$ and $4.75(1 \mathrm{H}, \mathrm{d}, J=7.5 \mathrm{~Hz})$, and two rhamnopyranosyl moieties at $\delta_{\mathrm{H}} 5.56(1 \mathrm{H}, \mathrm{d}, J=1.5 \mathrm{~Hz})$ and 4.47 $(1 \mathrm{H}, \mathrm{d}, J=1.3 \mathrm{~Hz})$ were observed, suggesting that compound 1 was a flavonoid tetraglycoside. The ${ }^{13} \mathrm{C}$-NMR spectrum of 1 (Table 1 ) showed signals equivalent to 39 carbons including kaempferol moiety, two $\beta$-glucopyranosyl moieties, and two $\alpha$-rhamnopyranosyl moieties. The attachment of sugar moieties was confirmed on the basis of the 2D NMR spectra including ${ }^{1} \mathrm{H}_{-}{ }^{1} \mathrm{H}$ COSY, HMQC, HMBC, and TOCSY. An anomeric proton at $\delta_{\mathrm{H}} 5.40(1 \mathrm{H}, \mathrm{d}, J=7.6 \mathrm{~Hz})$ showed a correlation with the C-3 carbon of kaempferol $\left(\delta_{\mathrm{C}} 135.0\right)$, suggesting that one glucopyranosyl moiety was attached at C-3 
of kaempferol. Similarly, another anomeric proton at $\delta_{\mathrm{H}} 4.75(1 \mathrm{H}, \mathrm{d}, J=7.5 \mathrm{~Hz})$ showed a correlation with the C-2 carbon of glucopyranosyl moiety $\left(\delta_{\mathrm{C}} 82.4\right)$ attached at C-3 of kaempferol. Furthermore, two anomeric protons for rhamnopyranosyl moiety at $\delta_{\mathrm{H}} 5.56(1 \mathrm{H}, \mathrm{d}, J=1.5 \mathrm{~Hz})$ and $4.47(1 \mathrm{H}, \mathrm{d}$, $J=1.3 \mathrm{~Hz})$ showed correlations with C-7 of kaempferol $\left(\delta_{\mathrm{C}} 163.5\right)$ and C-6 carbon of glucopyranosyl moiety $\left(\delta_{\mathrm{C}} 68.0\right)$ attached at C-3 of kaempferol, respectively. The key HMBC correlations are given in Figure 2. On the basis of this data, the structure of compound $\mathbf{1}$ was elucidated as kaempferol 3 -O- $\beta$-glucopyranosyl $(1 \rightarrow 2)$ - $\quad[\alpha$-rhamnopyranosyl $(1 \rightarrow 6)]-\beta$-glucopyranoside-7-O- $\alpha$-rhamnopyranoside. Previously, a minor quantity of compound 1 was isolated from the fruits of Styphnolobium japonicum (Leguminosae) [22] and as a mixture with kaempferol 3-O- $\beta$-glucopyranosyl $(1 \rightarrow 2)$ $[\alpha$-rhamnopyranosyl $(1 \rightarrow 6)]$-galactopyranoside-7-O- $\alpha$-rhamnopyranoside from the seed of Lens culinaris (Legumonosae) [23]. However, to the best of our knowledge, this is the first report on the isolation of 1 from the family Lauraceae.

Table 1. ${ }^{1} \mathrm{H}$ and ${ }^{13} \mathrm{C}-\mathrm{NMR}$ data of compound 1.

\begin{tabular}{|c|c|c|c|c|c|}
\hline Position & $\delta_{\mathrm{C}}$ & $\delta_{\mathrm{H}}$, mult. $(J$ in $\mathrm{Hz})$ & Position & $\delta_{\mathrm{C}}$ & $\delta_{\mathrm{H}}$, mult. $(J$ in $\mathrm{Hz})$ \\
\hline 2 & 159.6 & & $(2 \rightarrow 1)$ Rha & & \\
\hline 3 & 135.0 & & 1 & 104.6 & $4.75, \mathrm{~d}(7.5)$ \\
\hline 4 & 179.7 & & 2 & 75.5 & $3.38, \mathrm{~m}$ \\
\hline 5 & 162.8 & & 3 & 77.9 & $3.38, \mathrm{~m}$ \\
\hline 6 & 100.6 & $6.46, \mathrm{~d}(2.1)$ & 4 & 71.2 & $3.36, \mathrm{~m}$ \\
\hline 7 & 163.5 & & 5 & 78.4 & $3.30, \mathrm{~m}$ \\
\hline 8 & 95.8 & $6.74, \mathrm{~d}(2.1)$ & 6 & 62.6 & $3.80, \mathrm{~m} ; 3.70, \mathrm{~m}$ \\
\hline 9 & 158.0 & & $(6 \rightarrow 1)$ Rha & & \\
\hline 10 & 107.4 & & 1 & 102.1 & $4.47, \mathrm{~d}(1.3)$ \\
\hline $1^{\prime}$ & 122.6 & & 2 & 72.0 & $3.54, \mathrm{~m}$ \\
\hline $2^{\prime}$ & 132.4 & $8.05, \mathrm{~d}(8.8)$ & 3 & 72.2 & $3.54, \mathrm{~m}$ \\
\hline $3^{\prime}$ & 116.3 & $6.91, \mathrm{~d}(8.8)$ & 4 & 73.6 & $3.22, \mathrm{~m}$ \\
\hline $4^{\prime}$ & 161.6 & & 5 & 69.6 & $3.40, \mathrm{~m}$ \\
\hline $5^{\prime}$ & 116.3 & $6.91, \mathrm{~d}(8.8)$ & 6 & 17.8 & $1.07, \mathrm{~d}(6.1)$ \\
\hline $6^{\prime}$ & 132.4 & $8.05, \mathrm{~d}(8.8)$ & 7-O-Rha & & \\
\hline 3-O-Glc & & & 1 & 99.9 & $5.56, \mathrm{~d}(1.5)$ \\
\hline 1 & 100.9 & $5.40, \mathrm{~d}(7.6)$ & 2 & 71.6 & $4.02, \mathrm{dd}(1.5,3.3) \mathrm{m}$ \\
\hline 2 & 82.4 & $3.74, \mathrm{~m}$ & 3 & 72.0 & $3.82, \mathrm{~m}$ \\
\hline 3 & 77.7 & $3.60, \mathrm{~m}$ & 4 & 73.8 & $3.47, \mathrm{~m}$ \\
\hline 4 & 71.3 & $3.30, \mathrm{~m}$ & 5 & 71.3 & $3.62, \mathrm{~m}$ \\
\hline 5 & 77.0 & $3.30, \mathrm{~m}$ & 6 & 18.1 & $1.26, \mathrm{~d}(6.1)$ \\
\hline 6 & 68.0 & $3.80, \mathrm{~m} ; 3.36, \mathrm{~m}$ & & & \\
\hline
\end{tabular}

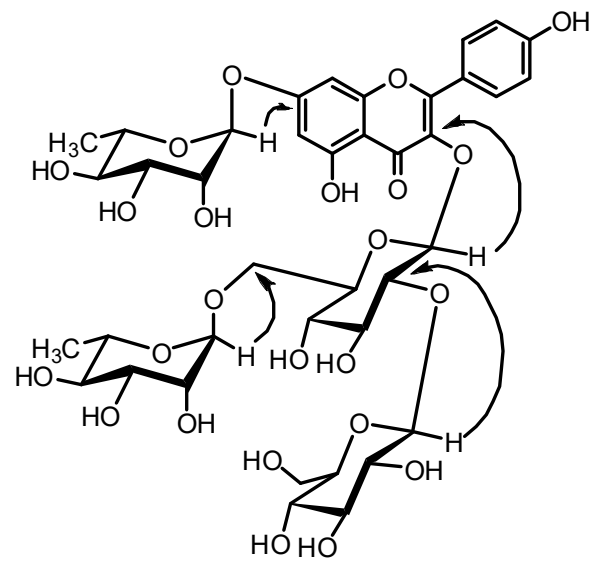

Figure 2. Key HMBC correlations of compound 1.

Other compounds were identified as kaempferol 3-O- $\beta$-glucopyranosyl $(1 \rightarrow 2)$ - $[\alpha$-rhamnopyranosyl $(1 \rightarrow 6)$ ]- $\beta$-glucopyranoside (2) [22], kaempferol 3-O- $\beta$-glucopyranosyl $(1 \rightarrow 2)$ - $\alpha$-rhamnopyranoside-7- 
O- $\alpha$-rhamnopyranoside (3) [24], kaempferol 3-O-sophoroside (4), and kaempferol 3-O-rhamnopyranoside (5) [24] on the basis of their NMR spectral data and comparison with literature values. This is the first report on the isolation of these kaempferol glycosides from the leaves and twigs of Lindera neesiana.

The hydroalcoholic extract and isolated compounds were evaluated for their free radical scavenging activity by DPPH method. The extract showed moderate free radical scavenging activity but the compounds were either very weak or inactive (Table 2). There is a possibility that the extract contains other active molecules which were not isolated in this study. Further bioassay guided isolation and identification of active compounds should be performed in future.

Table 2. $\mathrm{IC}_{50}$ values $(\mu \mathrm{g} / \mathrm{mL})$ of extract and compounds for free radical scavenging and lipase inhibitory activities.

\begin{tabular}{|c|c|c|}
\hline Samples & DPPH Free Radical Scavenging Activity ${ }^{a}$ & Lipase Inhibitory Activity $^{a}$ \\
\hline $60 \% \mathrm{EtOH}$ extract & $29.5 \pm 1.04$ & $3.14 \pm 0.76$ \\
\hline 1 & $130.22 \pm 7.078$ & $\mathrm{NA}^{\mathrm{b}}$ \\
\hline 2 & $\mathrm{NA}^{\mathrm{b}}$ & $\mathrm{NA}^{\mathrm{b}}$ \\
\hline 3 & $354.26 \pm 38.55$ & $\mathrm{NA}^{\mathrm{b}}$ \\
\hline 4 & $131.65 \pm 7.67$ & $19.56 \pm 0.40$ \\
\hline 5 & $200.96 \pm 17.52$ & $22.35 \pm 0.85$ \\
\hline Trolox $^{c}$ & $12.03 \pm 0.25$ & - \\
\hline Cetilistat $^{\mathrm{c}}$ & - & $3.85 \pm 0.40$ \\
\hline
\end{tabular}

a Values are expressed as the mean $\pm \mathrm{SD}(\mathrm{n}=3),{ }^{\mathrm{b}}$ not active; ${ }^{\mathrm{c}}$ Trolox and Cetilistat as positive controls in DPPH free radical scavenging and pancreatic lipase inhibitory activity assays, respectively.

\section{Conclusions}

Five kaempferol glycosides were isolated and identified from the hydroalcoholic extract of the leaves and twigs of Lindera neesiana. The extract showed potent pancreatic lipase inhibitory activity. Further studies should focus on the isolation and identification of active compounds and detailed exploration of their activities in vivo.

Author Contributions: A.A.-D. and H.P.D. conceived and designed the experiments; A.A.-D., A.I.D., A.K., K.T. and H.P.D. performed the experiments and analyzed the data; A.A.-D. and H.P.D. wrote the paper. All authors checked and approved the final version of manuscript.

Funding: This work was supported in part by Program for Leading Graduate Schools "HIGO" (Health life science: Interdisciplinary and Glocal Oriented), MEXT, Japan.

Acknowledgments: We are grateful to Ms. Teruo Tanaka and Toshiyuki Iriguchi of Institute of Resource Development and Analysis, Kumamoto University for NMR and MS analysis.

Conflicts of Interest: Authors declare no conflict of interest.

\section{References}

1. Cao, Y.; Xuan, B.; Peng, B.; Li, C.; Chai, X.; Tu, P. The genus Lindera: a source of structurally diverse molecules having pharmacological significance. Phytochem. Rev. 2016, 15, 869-906. [CrossRef]

2. Manandhar, N.P. Plants and People of Nepal; Timber Press, Inc.: Portland, OR, USA, 2002.

3. Wang, J.W.; Chen, X.Y.; Hu, P.Y.; Tan, M.M.; Tang, X.G.; Huang, M.C.; Lou, Z.H. Effects of linderae radix extracts on a rat model of alcoholic liver injury. Exp. Ther. Med. 2016, 11, 2185-2192. [CrossRef] [PubMed]

4. Chang, Y.C.; Chang, F.R.; Wu, Y.C. The constituents of Lindera glauca. J. Chin. Chem. Soc. 2000, 47, 373-380. [CrossRef]

5. Gan, L.S.; Zheng, Y.L.; Mo, J.X.; Liu, X.; Li, X.H.; Zhou, C.X. Sesquiterpene lactones from the root tubers of Lindera aggregata. J. Nat. Prod. 2009, 72, 1497-1501. [CrossRef] [PubMed]

6. Phan, B.H.; Seguin, E.; Tillequin, F.; Koch, M. Aporphine alkaloids from Lindera myrrha. Phytochemistry 1994, 35, 1363-1365. [CrossRef]

7. Huh, G.W.; Park, J.H.; Kang, J.H.; Jeong, T.S.; Kang, H.C.; Baek, N.I. Flavonoids from Lindera glauca Blume as low-density lipoprotein oxidation inhibitors. Nat. Prod. Res. 2014, 28, 831-834. [CrossRef] [PubMed] 
8. Ichino, K. Two flavonoids from two Lindera umbellata varieties. Phytochemistry 1989, 28, 955-956. [CrossRef]

9. Li, Y.M.; Ohno, Y.; Minatoguchi, S.; Fukuda, K.; Ikoma, T.; Ohno, T.; Akao, S.; Takemura, G.; Gotou, K.; Fujiwara, H. Extracts from the roots of Lindera strychifolia induces apoptosis in lung cancer cells and prolongs survival of tumor-bearing mice. Am. J. Chin. Med. 2003, 31, 857-869. [CrossRef]

10. Yan, R.; Yang, Y.; Zeng, Y.; Zou, G. Cytotoxicity and antibacterial activity of Lindera strychnifolia essential oils and extracts. J. Ethnopharmacol. 2009, 121, 451-455. [CrossRef] [PubMed]

11. Maeda, H.; Yamazaki, M.; Katagata, Y. Kuromoji (Lindera umbellata) essential oil inhibits LPS-induced inflammation in RAW 264.7 cells. Biosci. Biotechnol. Biochem. 2013, 77, 482-486. [CrossRef] [PubMed]

12. Yang, C.P.; Huang, G.J.; Huang, H.C.; Chen, Y.C.; Chang, C.I.; Wang, S.Y.; Chen, I.S.; Tseng, Y.H.; Chien, S.C.; Kuo, Y.H. A new butanolide compound from the aerial part of Lindera akoensis with anti-inflammatory activity. Molecules 2012, 17, 6585-6592. [CrossRef] [PubMed]

13. Shimomura, M.; Ushikoshi, H.; Hattori, A.; Murata, I.; Ohno, Y.; Aoyama, T.; Kawasaki, M.; Nishigaki, K.; Takemura, G.; Fujiwara, T.; et al. Treatment with Lindera strychnifolia Reduces Blood Pressure by Decreasing Sympathetic Nerve Activity in Spontaneously Hypertensive Rats. Am. J. Chin. Med. 2010, 38, 561-568. [CrossRef] [PubMed]

14. Ruehl, M.; Erben, U.; Kim, K.; Freise, C.; Dagdelen, T.; Eisele, S.; Trowitzsch-Kienast, W.; Zeitz, M.; Jia, J.; Stickel, F.; et al. Extracts of Lindera obtusiloba induce antifibrotic effects in hepatic stellate cells via suppression of a TGF- $\beta$-mediated profibrotic gene expression pattern. J. Nutr. Biochem. 2009, 20, 597-606. [CrossRef] [PubMed]

15. Xu, C.; Yang, B.; Zhu, W.; Li, X.; Tian, J.; Zhang, L. Characterisation of polyphenol constituents of Linderae aggregate leaves using HPLC fingerprint analysis and their antioxidant activities. Food Chem. 2015, 186, 83-89. [CrossRef] [PubMed]

16. Hosseinzadeh, M.; Hadi, A.H.; Mohamad, J.; Khalilzadeh, M.A.; Cheahd, S.C.; Fadaeinasab, M. Flavonoids and linderone from Lindera oxyphylla and their bioactivities. Comb. Chem. High Throughput Screen 2013, 16, 160-166. [PubMed]

17. Watanabe, T.; Rajbhandari, K.R.; Malla, K.J.; Devkota, H.P.; Yahara, S. A Handbook of Medicinal Plants of Nepal Supplement I; Ayurseed L.E.I.: Kanagawa, Japan, 2013.

18. Subedi, L.; Gaire, B.P.; Do, M.H.; Lee, T.H.; Kim, S.Y. Anti-neuroinflammatory and neuroprotective effects of the Lindera neesiana fruit in vitro. Phytomedicine 2016, 23, 872-881. [CrossRef] [PubMed]

19. Comai, S.; Dall'Acqua, S.; Grillo, A.; Castagliuolo, I.; Gurung, K.; Innocenti, G. Essential oil of Lindera neesiana fruit: Chemical analysis and its potential use in topical applications. Fitoterapia 2010, 81, 11-16. [CrossRef]

20. Devkota, H.P.; Kurizaki, A.; Tsuhiro, K.; Hori, K.; Wada, M.; Watanabe, T. Medicinal Plants as Source of Potent Bioactive Natural Products and Functional Foods. In Proceedings of the Proceeding of Japan-Turkey International Symposium on Pharmaceutical and Biomedical Sciences, Kumamoto, Japan, 2-3 October 2016; p. 16.

21. Dirar, A.I.; Alsaadi, D.H.M.; Wada, M.; Mohamed, M.A.; Watanabe, T.; Devkota, H.P. Effects of extraction solvents on total phenolic and flavonoid contents and biological activities of extracts from Sudanese medicinal plants. S. Afr. J. Bot. 2019, 120, 261-267. [CrossRef]

22. Kite, G.C.; Veitch, N.C.; Boalch, M.E.; Lewis, G.P.; Leon, C.J.; Simmonds, M.S.J. Flavonol tetraglycosides from fruits of Styphnolobium japonicum (Leguminosae) and the authentication of Fructus Sophorae and Flos Sophorae. Phytochemistry 2009, 70, 785-794. [CrossRef]

23. Taylor, W.G.; Fields, P.G.; Sutherland, D.H. Fractionation of lentil seeds (Lens culinaris Medik.) for insecticidal and flavonol tetraglycoside components. J. Agric. Food Chem. 2007, 55, 5491-5498. [CrossRef]

24. Kucukislamoglu, M.; Yayli, N.; Şentürk, H.B.; Genç, H.; Özden, S. Flavonol glycosides from Consolida armeniaca. Turk. J. Chem. 2000, 24, 191-197.

(C) 2019 by the authors. Licensee MDPI, Basel, Switzerland. This article is an open access article distributed under the terms and conditions of the Creative Commons Attribution (CC BY) license (http://creativecommons.org/licenses/by/4.0/). 